\title{
A Prefatory Note
}

In shaping a collection as large and diverse as the present one the editors have incurred many debts of gratitude. Our first and most enduring indebtedness is expressed on the dedication page; the existence of this volume reflects the depth of that indebredness. Next, we must thank all our contributors, both for their essays and for their exceptionally cooperative spirit in helping us bring those essays into an interlocking relation with each other. The idea for a volume like this one was first proposed by one contributor, Robert L. Patten; we are especially grateful to him. Another contributor, A. Walton Litz, gave us support and encouragement from the earliest stages of this undertaking; moreover, he helped us to keep always in mind the end toward which the work was directed.

The enthusiasm for the project shown at the outset by William J. McClung at the University of California Press and his later aid and advice were invaluable in bringing the work to fruition. He has our sincerest thanks. We are also grateful to Doris Kretschmer, Wolfgang Lederer, Susan H. Peters, and Linda Rageh for their interest and cooperation at different stages of production. The very considerable task of typing the entire manuscript in final form was ably carried out by Ellen Cole and the staff of the Central Stenographic Bureau at the University of California at Los Angeles. Both editors benefited from support from the Research Committees of the University of California at Berkeley and Los Angeles.

We are grateful to Her Majesty the Queen for permission to reproduce Sir Edwin Landseer's painting of Queen Victoria, Prince Albert, and the Princess Royal (illustration 33). We also want to thank the following collectors, institutions, and museums for allowing us to reproduce works in their collections: Ashmolean Museum, Oxford (illustrations 98 and 102); Sanford and Helen Berger (illustrations 46, 47, 48); City Museum and Art Gallery, Birmingham (frontispiece; illustrations 69, 71, 74, 94, 99, 103, 104, 105, 116, 117); Public Library and Art Museum, Bury (illustration 79); Sir Francis Cooper, Bt. (illustration 80); Chicago Art Institute (illustration 81); Terence Davis (illustration 35); George Eastman House, Rochester, New York (illustrations 1, 2, 3, 4, 6, 9, 10, 16, 17, 18, 19); Fogg Art Museum, Harvard University (illustration 88); Forbes Magazine Collection (illustration 111); Kunsthalle, Hamburg (illustration 62); City Art Gallery, Leeds (illustrations 110, 112); Liverpool Record Office (illustration 36); London Victorian Society (illustrations 41, 43, 53, 55, 56); City Art Gallery, Manchester (illustrations 32, 92, 118); Metropolitan Museum, New York (illustrations 12 and 13); Dr. Eva Reichmann (illustration 129); Royal British Institute of Architects, London (illustration 60); Collection Lord Sherfield, 
Royal Academy (illustration 97); Tate Gallery, London (illustrations 82, 83, 90, 93, 95, 96, 114); Victoria and Albert Museum, London (illustrations 28, 49, 85, 86, 87, 89, and 91); Wadsworth Atheneum, Hartford, Connecticut (illustration 100); Walker Gallery, Liverpool (illustration 119).

Finally, for their cooperation and hospitality through many meetings and consultations, we express our thanks to our wives.

U. C. K.

G. B. T. 